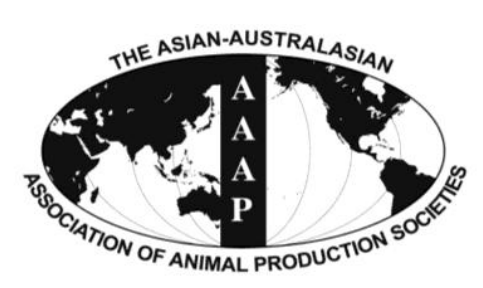

\title{
Seamustard (Undaria pinnatifida) Improves Growth, Immunity, Fatty Acid Profile and Reduces Cholesterol in Hanwoo Steers
}

\author{
J. A. Hwanga , M. M. Islamª , S. T. Ahmed, H. S. Mun, G. M. Kim, Y. J. Kim, and C. J. Yang* \\ Department of Animal Science and Technology, Sunchon National University, Suncheon 540-742, Korea
}

\begin{abstract}
The study was designed to evaluate the effect of $2 \%$ seamustard (Undaria pinnatifida) by-product (SW) on growth performance, immunity, carcass characteristics, cholesterol content and fatty acid profile in Hanwoo steers. A total of 20 Hanwoo steers (ave. 22 months old; $619 \mathrm{~kg}$ body weight) were randomly assigned to control (basal diet) and 2\% SW supplemented diet. Dietary SW supplementation significantly $(\mathrm{p}<0.05)$ improved average daily gain and gain:feed ratio as well as serum immunoglobulin $\mathrm{G}$ concentration. Chemical composition and quality grade of meat and carcass yield grades evaluated at the end of the trial were found to be unaffected by SW supplementation. Dietary SW significantly reduced meat cholesterol concentration $(\mathrm{p}<0.05)$. Dietary SW supplementation significantly reduced the myristic acid (C14:0) and palmitoleic acid (C16:ln-7) concentration, while SW increased the concentration of stearic acid (C18:0) and linolenic acid (C18:3n-3) compared to control ( $<<0.05)$. Dietary SW supplementation had no effect on saturated fatty acids (SFA), unsaturated fatty acids, poly unsaturated fatty acid (PUFA) or mono unsaturated fatty acid content in muscles. A reduced ratio of PUFA/SFA and $n-6 / n-3$ were found in SW supplemented group ( $p<0.05$ ). In conclusion, $2 \%$ SW supplementation was found to improve growth, immunity and fatty acid profile with significantly reduced cholesterol of beef. (Key Words: Seaweed, Immunity, Carcass Quality, Cholesterol, Fatty Acid, Hanwoo Steer)
\end{abstract}

\section{INTRODUCTION}

Hanwoo (Korean native) cattle are known to have relatively good reproduction abilities but are poor in meat and milk production because of their slow growth rate and milk capacity. Hanwoo beef is enthusiastically preferred to imported beef in Korean markets, despite it being twice as expensive, because Korean consumers believe that Hanwoo beef is fresher and has better quality than imported beef (Kim et al., 2000; Han and Lee, 2010). Meat and meat products are a vital part of a healthy diet and are important sources of nutrients but they are also associated with the negative image as sources of fat, saturated fatty acids (SFA) and cholesterol, which are associated with heart disease, cancer and obesity. The taste depends on the quality, health and flavor of beef. Quality of fat is determined by fatty acid

\footnotetext{
* Corresponding Author: Chul-Ju Yang. Tel: +82-61-750-3235, Fax: +82-61-750-3239, E-mail: yangcj@scnu.kr

${ }^{a}$ These authors contributed equally to this work.

Submitted Jan. 29, 2014; Revised Mar. 31, 2014; Accepted Apr. 10, 2014
}

composition and beef quality depends not only on the marbling score but also on fatty acid composition (Cameron and Enser, 1991; Laborde et al., 2001). These factors are of considerable interest because of their implications for human health. The SFAs raise total blood cholesterol and low-density lipoprotein (LDL) levels and are associated with the risk of cardiovascular disease, whereas mono unsaturated fatty acids (MUFAs) reduce the level of plasma LDL cholesterol without depressing the strong antiatherogenic activity of high density lipoprotein-cholesterol lipoproteins (Mattson and Grundy, 1985).

Marine macroalgae (seaweeds) can be considered as eco-feed as it is rich in bioactive compounds that could potentially be exploited as functional ingredients for both human and animal health applications (Gupta and AbuGhannam, 2011). Seamustard, also known as wakame (Undaria pinnatifida) is a large brown seaweed belonging to the order Laminariales. The nutritional value of seaweed as a feed supplement for domestic animals has been confirmed by many authors (Zalabak et al., 1990; Arieli et al., 1993; Applegate and Gray, 1995) and speculated as the

Copyright $@ 2014$ by Asian-Australasian Journal of Animal Sciences This is an open-access article distributed under the terms of the Creative Commons Attribution Non-Commercial License (http://creativecommons.org/licenses/by-nc/3.0/), which permits unrestricted non-commercial use, distribution, and reproduction in any medium, provided the original work is properly cited. 
valuable feed source for livestock in the future. Phlorotannins occur only in marine brown algae and are produced entirely by polymerization of phloroglucinol (1,3,5-trihydroxybenzene) through carbon-carbon or carbon-oxygen bonds (Ragan and Glombitza, 1986; Arnold and Targett, 1998), have been studied extensively with regard to their effects on ruminant nutrition, especially in relation to protein metabolism by rumen microflora (Barry and McNabb, 1999; Min et al., 2003). Seaweed is suitable as an ingredient of ruminants' diet with a high-energy content (Arieli et al., 1993). Edible seaweeds contain acceptable amounts of protein and their amino acid compositions are of nutritional interest (Fleurence, 1999; Kolb et al., 2004). Furthermore, in addition to the deposition of bioactive compounds in muscle tissues of meat producing animals, dietary bioactive compounds have also demonstrated the potential to improve animal health and welfare.

Today, the livestock industry is facing a problem due to the high cost of feed caused by continued increases in world grain prices. On the other hand, a tremendous amount of seamustard ( $U$. pinnatifida) by-product $(\mathrm{SW})$ separated during the processing of seaweed is thrown into the sea where it pollutes the environment and marine ecosystem. In 2013 , total seaweed production in Jeonnam province was approximately 1 million ton $(70 \%$ to $80 \%$ of total seaweed production in Korea) out of which 45,000 to 50,000 tons are discarded as wakame and other seaweed by-products yearly (OFSI, 2013). Few scientific studies have addressed the potential for incorporating health promoting bioactive compounds derived from seaweed into muscle foods via the supplementation of animal diets. Brown seaweed (Ascophyllum nodosum) meal or extracts as natural feed additives for pigs (Turner et al., 2002), lambs (Saker et al., 2004) and beef cattle (Allen et al., 2001; Fike et al., 2001) were investigated earlier. Supplementation with $2 \% A$. nodosum meal to cattle diet increased intramuscular fat, improved carcass quality and extended beef shelf life (Branden et al., 2007). Phlorotannins from brown seaweed have been reported as possessing several biological activities such as antioxidant and preventing skin carcinogenesis (Nakamura et al., 1996; Hwang et al., 2006). Seaweed extract improved the cellular MUFA in the adipocytes (Cherian et al., 2002). However, dietary supplementation of SW in ruminants' diet would be a new approach. Thus, the objective of this study was to assess the effect of dietary supplementation of SW on growth performance, immunity, carcass characteristics, meat quality and fatty acid profile in Hanwoo steers.

\section{MATERIALS AND METHODS}

The use and care of steers were carried out in accordance with the guidelines for the care and use of animals in research (Korean Ministry for Food Agriculture Forestry and fisheries, 2008). All experimental procedures used in this study were approved by the Animal Care and Use Committee of Sunchon National University.

\section{Animal, experimental design and diet}

The study was conducted from April 2012 to October 2012 at the experimental farm of Sunchon National University, Jeonnam, Korea. A total of 20 homogenous Hanwoo steers (ave. 22 months old; $619 \mathrm{~kg}$ body weight) were assigned to two dietary treatments with ten steers per treatment in a randomized manner. A group of two steers was considered as one replication. Experimental diets were control (basal diet) and 2\% SW (basal diet $+2.0 \%$ SW, dry matter (DM) basis). Steers were allowed one week for adaptation. A commercially available total mixed ration (Suncheon Gwangyang Livestock Co-operative, Yeonhyang-dong, Suncheon, Jeonnam, Korea) was used as the basal diet. The ingredients, chemical composition, and vitamin and mineral contents of the basal diets are shown in Table 1. The SW (roots and stems of $U$. pinnatifida) were collected from Goheung, Jeonnam, Korea which are separated during the processing of seaweed as human food. SW having $1.85 \%$ salinity, contains $89.67 \%$ moisture, $9.44 \%$ crude protein $(\mathrm{CP}), 0.68 \%$ crude fat, $6.93 \%$ crude fiber and $45.24 \%$ crude ash. The SW diet was prepared separately by adding fresh SW at $2.0 \%$ (on DM basis) by weight/weight ratio basis. The experimental feed was supplied twice per day in the morning and evening (15 $\mathrm{kg} / \mathrm{steer} / \mathrm{d})$. Water was supplied ad libitum. Lighting and other management were carried out in accordance with general practice.

\section{Measurements and analysis}

Growth performance: Body weight was measured before feeding and watering using a platform balance at the onset and end of the experiment. Feed bunks were cleaned and residues were collected daily and weighed at intervals corresponding to weigh dates. Gain:feed was calculated as the ratio between body weight gain and average feed intake.

Immunoglobulin quantification: To determine immunoglobulin $\mathrm{G}(\mathrm{IgG})$ and IgM levels, approximately 5.0 $\mathrm{mL}$ of blood was collected from the jugular vein. Samples were then centrifuged at 3,000 g for 15 minutes and serum was collected. The separated serum was then stored at $-20^{\circ} \mathrm{C}$ for further analysis. Serum $\mathrm{Ig}$ concentrations were assayed using bovine IgG and IgM enzyme-linked immunosorbent assay kits (Bethyl Laboratories Inc., Montgomery, TX, USA). Briefly, polystyrene 96-well microtitre plates (Falcon, 35-3072 Becton Dickinson, Montgomery, TX, USA) were coated with $100 \mu \mathrm{L} /$ well sheep anti-bovine affinity purified antigen diluted in $0.05 \mathrm{M}$ 
Table 1. Ingredients and chemical composition of experimental diet

\begin{tabular}{lcc}
\hline \multirow{2}{*}{ Item } & \multicolumn{2}{c}{ Treatment } \\
\cline { 2 - 3 } & Control & SW \\
\hline Ingredient (\% fed basis) & & \\
Concentrate feed & 17.03 & 17.03 \\
Corn, ground & 20.16 & 18.44 \\
Corn gluten feed & 7.74 & 7.74 \\
Wheat bran & 11.36 & 11.36 \\
Brewers grain & 8.32 & 8.32 \\
WCBS & 15.90 & 15.90 \\
Italian ryegrass & 11.36 & 11.36 \\
Tall fescue & 6.81 & 6.81 \\
Salt & 0.28 & 0.00 \\
Sea mustard by-product & 0 & 2.00 \\
Vitamin-mineral mix ${ }^{1}$ & 0.23 & 0.23 \\
Limestone & 0.81 & 0.81 \\
Chemical composition (\% DM) & & \\
TDN & 72.30 & 73.24 \\
CP & 8.48 & 8.90 \\
Crude fat & 1.55 & 1.38 \\
Crude fiber & 13.89 & 13.77 \\
Crude ash & 5.36 & 5.83 \\
ADF & 17.95 & 16.48 \\
NDF & 41.90 & 39.20 \\
NFC & 42.71 & 43.81 \\
\hline SW sa mur & &
\end{tabular}

SW, sea mustard (Undaria pinnatifida) by-product; WCBS, whole crop barley silage; DM, dry matter; TDN, total digestible nutrients; CP, crude protein; ADF, acid-detergent fiber; NDF, neutral detergent fiber; NFC, non-fibrous carbohydrate.

${ }^{1}$ Premix provided following nutrients per kg of diet: vitamin (Vit) A, 9,000,000 IU; Vit. $\mathrm{D}_{3}, 2,100,000 \mathrm{IU}$; Vit. E, $15,000 \mathrm{IU}$; Vit. K, 2,000 mg; Vit. $B_{1}, 1,500 \mathrm{mg}$; Vit. $\mathrm{B}_{2}, 4,000 \mathrm{mg}$; Vit. $\mathrm{B}_{6}, 3,000 \mathrm{mg}$; Vit. $\mathrm{B}_{12}, 15 \mathrm{mg}$; Pan-acid-Ca, 8,500 mg; Niacin, 20,000 mg; Biotin, $110 \mathrm{mg}$; folic-acid, $600 \mathrm{mg}$; Co, $300 \mathrm{mg}$; Cu, 3,500 mg; Mn, 55,000 mg; Zn, 40,000 mg; I, $600 \mathrm{mg} ; \mathrm{Se}, 130 \mathrm{mg}$.

NDF and ADF (as per Van Soest et al., 1991).

carbonate-bicarbonate buffer $(\mathrm{pH} 9.6)$ and incubated at room temperature $\left(20^{\circ} \mathrm{C}\right.$ to $\left.25^{\circ} \mathrm{C}\right)$ for 1 hour. Plates were then washed five times with wash solution $(50 \mathrm{mM}$ Tris, $0.14 \mathrm{M} \mathrm{NaCl}, 0.05 \%$ Tween $20, \mathrm{pH} 8.0$ ) and shaken to dry. Blocking solution $(200 \mu \mathrm{L}$ of $50 \mathrm{mM}$ Tris, $0.14 \mathrm{M} \mathrm{NaCl}$, $0.05 \%$ Tween $20, \mathrm{pH} 8.0$ ) was poured into each well and incubated for 30 minutes at room temperature. Plates were again washed five times with wash solution and $100 \mu \mathrm{L}$ of standard as well as sample was poured to the respective wells and incubated at room temperature for 1 hour. Plates were again washed, shaken to dry and $100 \mu \mathrm{L}$ of diluted horseradish peroxidase (HRP) detection antibody (sheep anti-bovine HRP conjugated antigen diluted in sample conjugated diluents, $100 \mathrm{~mL}$ post coat solution+0.5 mL $10 \%$ Tween 20) was then added to each well and incubated for 1 hour at room temperature. The plates were again washed as mentioned above, shaken to dry and then $100 \mu \mathrm{L}$ of tetramethylbenzidine substrate was added to each well. Plates were developed in the dark at room temperature for 15 minutes and the reaction was stopped by adding $100 \mu \mathrm{L}$ of stop solution to each well and measuring absorbance on a plate reader (Thermo Scientific, Multiskan GO, Vantaa, Finland) at $450 \mathrm{~nm}$. Tests were performed in duplicate.

Carcass grading and meat quality: All the steers were slaughtered in a commercial slaughterhouse of Suncheon city, South Korea. Carcasses were graded for quality and yield factors by a trained carcass evaluator in accordance with Korean beef carcass grading standards (KAPE, 2012). The quality of beef carcasses were graded using five grades $(1++, 1+, 1,2$, or 3$)$, principally based upon marbling scores and then adjusted according to other carcass traits such as meat color, fat color, texture of lean meat and maturity. One of three yield grades (A, B, or C) was determined by assessing live weight, carcass weight and back fat thickness at rib eye area.

\section{Chemical analysis}

Within approximately $2 \mathrm{~h}$ of slaughtering, samples were stored at $-20^{\circ} \mathrm{C}$ until required for analysis. To investigate meat chemical compositions, longissimus muscles from the loin area were selected and ground using a meat grinder. The moisture, $\mathrm{CP}$, crude fat and crude ash contents were determined using the AOAC methods (AOAC, 2000).

Cholesterol and fatty acid concentration: Cholesterol and fatty acids were determined using gas chromatography (DS 6200, Donam Co., Sungnam, Korea) according to specifications given in Table 2.

Cholesterol concentration was determined according to the methodology of King et al. (1998). Specifically, $1 \mathrm{~g}$ of each meat sample (mixed with reference material; $100 \mu \mathrm{g}$ of $5 \alpha$-cholestane) was homogenized with $50 \% \mathrm{KOH}$ (aq) and $22 \mathrm{~mL}$ of ethanol, followed by saponification at $23^{\circ} \mathrm{C}$ for 6 $\mathrm{h}$ and extraction several times.

Meat fatty acids were determined by the methyl ester extraction method described by Yang et al. (2003). Briefly, $1 \mathrm{~g}$ of each sample was dissolved separately into $100 \mathrm{~mL}$ of Folch solution (chloroform:methanol 2:1 v/v) for $15 \mathrm{~min}$. The samples were flushed with nitrogen gas for $30 \mathrm{~min}$ in an evaporator and filtered through a Buchner funnel. The filtrate was then dissolved in $70 \mathrm{~mL}$ of double distilled water and kept at $5^{\circ} \mathrm{C}$ in a refrigerator until the fat layer separated. After phase separation, the bottom layer was evaporated at $35^{\circ} \mathrm{C}$ with nitrogen gas and dissolved in $3 \mathrm{~mL}$ of $5 \%$ sulfuric acid methanol. The tubes were then heated in a water bath at $95^{\circ} \mathrm{C}$ for $45 \mathrm{~min}$ and allowed to cool at room temperature. After cooling, fatty acid methyl ester was extracted three times with $3 \mathrm{~mL}$ of petroleum ether and dried with nitrogen gas. Samples were loaded on to the column via $1 \mu \mathrm{L}$ splitless injections maintaining the 
Table 2. Gas chromatography analysis conditions for cholesterol and fatty acid

\begin{tabular}{|c|c|c|}
\hline \multirow{2}{*}{ Item } & \multicolumn{2}{|c|}{ Condition } \\
\hline & Cholesterol & Fatty acid \\
\hline Machine & DS 6200 (Korea) & DS 6200 (Korea) \\
\hline Detector & FID $270^{\circ} \mathrm{C}$ & FID $270^{\circ} \mathrm{C}$ \\
\hline Injector & Capillary ING $250^{\circ} \mathrm{C}$ & Capillary ING $250^{\circ} \mathrm{C}$ \\
\hline Column & $\begin{array}{c}\text { HP-5 } \\
(\mathrm{J} \& \mathrm{~W}, 30 \mathrm{~m} \times 0.32 \mathrm{~mm}, 0.25 \mu \mathrm{m} \text { film thickness })\end{array}$ & $\begin{array}{c}\text { HP-5 } \\
(\mathrm{J} \& \mathrm{~W}, 30 \mathrm{~m} \times 0.32 \mathrm{~mm}, 0.25 \mu \mathrm{m} \text { film thickness })\end{array}$ \\
\hline Carrier gas flow & Nitrogen $(1.0 \mathrm{~mL} / \mathrm{min})$ & Nitrogen $(1.0 \mathrm{~mL} / \mathrm{min})$ \\
\hline Make up gas flow & $\mathrm{H}_{2}(3.0 \mathrm{~mL} / \mathrm{min})$ & $\mathrm{H}_{2}(3.0 \mathrm{~mL} / \mathrm{min})$ \\
\hline Oven temperature $\left({ }^{\circ} \mathrm{C}\right)$ & 250 & 140 \\
\hline Detector temperature $\left({ }^{\circ} \mathrm{C}\right)$ & 280 & 270 \\
\hline Injector temperature $\left({ }^{\circ} \mathrm{C}\right)$ & 280 & 250 \\
\hline Temperature program & $\begin{array}{c}250^{\circ} \mathrm{C}(2 \mathrm{~min})-15^{\circ} \mathrm{C} / \mathrm{min}-290^{\circ} \mathrm{C}(10 \mathrm{~min})- \\
10^{\circ} \mathrm{C} / \mathrm{min}-310^{\circ} \mathrm{C}(10 \mathrm{~min})\end{array}$ & $\begin{array}{c}140^{\circ} \mathrm{C}(1 \mathrm{~min})-10^{\circ} \mathrm{C} / \mathrm{min}-220^{\circ} \mathrm{C}(2 \mathrm{~min})-2^{\circ} \mathrm{C} / \mathrm{min}- \\
240^{\circ} \mathrm{C}(9 \mathrm{~min})\end{array}$ \\
\hline Split ratio & $50: 1$ & $50: 1$ \\
\hline Injection volume $(\mu \mathrm{L})$ & 2 & 1 \\
\hline
\end{tabular}

conditions described in Table 2.

\section{Statistical analysis}

Data were analyzed by analysis of variance using the general linear model procedure of SAS (SAS, 2003). For growth performance parameters, a group of two steers served as experimental unit. For carcass characteristics, meat composition, cholesterol content and fatty acid profile of meat, individual steer served as the experimental unit. Variability in data was expressed as the pooled s.e. and the $\alpha$-level for analysis was $<0.05$, with $p$-values $>0.05$ and $<0.10$ considered as tendencies.

\section{RESULTS AND DISCUSSION}

\section{Growth performance}

Tannins are naturally occurring plant polyphenolic compounds found in terrestrial and marine plants (Haslam, 1989; Waterman and Mole, 1994). Effects of tannin content in terrestrial plants (terrestrial tannins) have been studied extensively with regard to their effects on ruminant nutrition, especially in relation to protein metabolism by rumen microflora (Barry and McNabb, 1999; Min et al., 2003; Mueller-Harvey, 2006). Phlorotannins (PT) are tannin derivatives synthesized via the acetate-malonate pathway are stored in special vesicles (physodes) and are thought to be the defense compounds in brown seaweeds. Molecular sizes of PT range from 400 to 400,000 Da, and their concentrations in the epidermal cortex of brown algae vary from 5 to $200 \mathrm{~g}$ per kg DM (Ragan and Glombitza, 1986). Beneficial effects of low- to medium concentrations (5 to $50 \mathrm{~g} / \mathrm{kg} \mathrm{DM}$ ) of tannins in ruminant diets include reduction in the incidence of pasture bloat and improved protein utilization and animal productivity (Wang et al., 1996; Min et al., 1998; Wang et al., 2006).
The effect of SW supplementation on the growth performance of Hanwoo steers is shown in Table 3. Initial and final body weights were not statistically different between treatments. The average daily gain (ADG) of Hanwoo steers was increased in SW supplemented group compared to control $(\mathrm{p}<0.05)$. By contrast, Al-Shorepy et al. (2001) and Bach et al. (2008) did not find any significant variation in weight gain in lambs fed supplementary dietary seaweed. Similarly, Anderson et al. (2006) found no significant effect of seaweed inclusion on ADG or feed efficiency of English crossbred cattle. However, dietary seaweed increased ADG in pig (Turner et al., 2002; O'Doherty et al., 2010) and also increased lambs' birth weight maintaining normal body weight in sheep (McHugh, 2003; Hertz 2008, personal communication). Fike et al. (2001) reported a linear increase in lamb weight gain in response to Tasco (a proprietary brown seaweed-based product) during the summer grazing period. Degradable protein is used by ruminal microbes, to convert feed nutrients to microbial protein, rather than by the animal

Table 3. Effect of sea mustard (Undaria pinnatifida) by-product (SW) on growth performance of Hanwoo steers for 180 days ${ }^{1}$

\begin{tabular}{lcccc}
\hline \multirow{2}{*}{ Parameter } & \multicolumn{2}{c}{ Treatment } & Pooled & \multirow{2}{*}{ SE } \\
\cline { 2 - 3 } & Control & $\mathrm{SW}$ & $\mathrm{S}$ & \\
\hline $\begin{array}{l}\text { Initial body weight } \\
(\mathrm{kg} / \mathrm{steer})\end{array}$ & 617.75 & 621.88 & 10.46 & 0.80 \\
$\begin{array}{l}\text { Final body weight } \\
\quad(\mathrm{kg} / \mathrm{steer})\end{array}$ & 749.42 & 773.21 & 11.52 & 0.20 \\
ADG (kg/steer) & 0.73 & 0.84 & 0.03 & 0.05 \\
ADFI (kg DM/steer) & 11.36 & 11.23 & 0.03 & 0.02 \\
Gain:feed & 0.06 & 0.08 & 0.003 & 0.02 \\
\hline
\end{tabular}

Pooled SE, pooled standard error; ADG, average daily gain; ADFI, average daily feed intake; DM, dry matter.

${ }^{1}$ Data presented as the mean value of five replicate groups with two steers per replication $(\mathrm{n}=10)$.

Significantly differed $(\mathrm{p}<0.05)$; tendency $(\mathrm{p}<0.10)$. 
itself whereas increasing the undegradable protein in the diet elevates the amino acid flow in the small intestine. Both -phlorotannins and terrestrial tannins have been shown to form complexes with proteins and reduce their degradability in the rumen, which ultimately improves animal productivity (Ragan and Glombitza, 1986; Haslam, 1989). Increased ADG of Hanwoo steers in the present study may be due to the effect of terrestrial tannin contents of $U$. pinnatifida. Mueller-Harvey (2006) stated that tannins have the ability to reduce microbial degradation of plant protein, thus improving protein utilization in ruminants. An increased percentage of rumen undegradable protein increased amino acid flow to the small intestine and a possible improvement in amino acid absorption and complement of amino acids absorbed resulting in the improved growth of animals (Harvey et al., 1982; Zerbini and Polan, 1985; Klopfenstein and Goedeken, 1986). However, in the present study, significantly decreased average daily feed intake (ADFI) and increased gain:feed was found in the SW dietary group compared to control $(p<0.05)$. The increased feed efficiency may be the result of improved weight gain and increase in the rumen undegradable protein in the diets (Zerbini and Polan, 1985; Swartz et al., 1989; Tomlinson et al., 1989; Tomlinson et al., 1997).

\section{Immunoglobulin (IgG and IgM)}

Brown seaweed possesses a considerable number of potentially useful bioactive compounds (Holdt and Kraan, 2011). These bioactive compounds in seaweeds include; sulphated polysaccharides (e.g., fucose containing polymers), laminarin, phlorotannins and diterpenes that have potential applications for their antimicrobial, immunemodulating and antioxidant properties (Kandasamy et al., 2012). The SW supplementation significantly increased $(\mathrm{p}<0.05) \quad \operatorname{IgG}$ concentrations while IgM concentrations remained unaffected (Table 4$)$. Earlier studies on the dietary inclusion of brown seaweed meal (A. nodosum) found that it enhanced immunity and antioxidant properties in cattle (Allen et al., 2001; Fike et al., 2001). Bach et al. (2008) reported that supplementation of brown seaweed extracts

Table 4. Effect of dietary sea mustard ( Undaria pinnatifida) by-product (SW) on serum immunoglobulin level of Hanwoo steers ${ }^{1}$

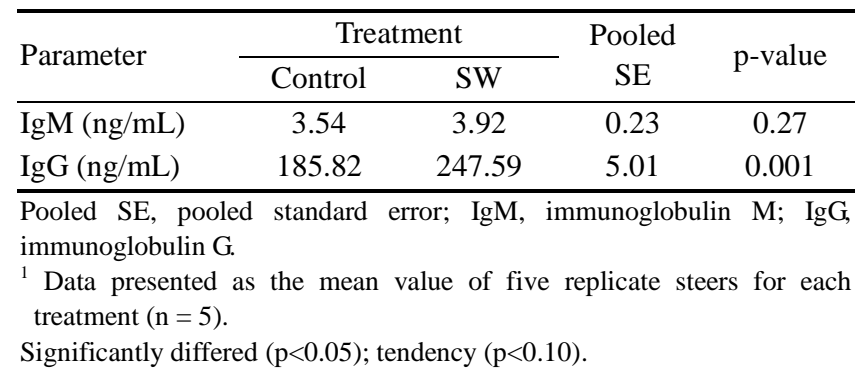

improved the immune system and boosted the immunity of lambs. Read et al. (1996) reported that the immune modulating properties of laminarin (a novel source of $\beta$-(1$3) /(1-6)$ glucans), rich in brown seaweed, are responsible for increased colostral $\mathrm{IgG}$ concentrations in seaweed extract supplemented sows. The water soluble $\beta$-glucans are known to stimulate host immune function by activating dectin-1 receptors expressed on the cell surfaces of monocytes, macrophages and neutrophils (Brown and Gordon, 2005; Volman et al., 2008). Administration of yeast-derived $\beta$-glucans to pregnant mares increased colostral IgG concentrations, indicating that $\beta$-glucans have a nonspecific immunomodulatory property (Krakowski et al., 1999). Another compound, laminarin, is speculated to potentiate a nonspecific immune response in supplemented sows, and was responsible for increased colostral IgG concentrations (Leonard et al., 2010). Saker et al. (2001) reported that a brown seaweed (A. nodosum) extract treated Tasco-forage enhanced the immune system of feedlot finishing cattle. According to Le Tutour (1990) seaweeds contain substituted phenols and polyphenols, a class of compounds with antioxidant activity, is essential for mediating and protecting the immune system (Dubeski, 1999).

\section{Meat characteristics and chemical composition}

The effect of SW supplementation on Hanwoo carcass characteristics and meat chemical composition is shown in Table 5 and 6, respectively. Dietary SW supplementation did not affect carcass characteristics and meat quality grades. The absence of significant changes in carcass weight, yield index and carcass yield grade between the treatments may be the result of body weight during slaughter and its effect on fattiness (Preston and Willis, 1974). Mohammed et al. (2007) found that all carcass measurements are significantly affected by slaughter weight. However, in the present study, the addition of SW had no

Table 5. Effect of sea mustard ( Undaria pinnatifida) byproduct (SW) on carcass characteristics and meat quality of Hanwoo steers ${ }^{1}$

\begin{tabular}{lcccc}
\hline \multirow{2}{*}{ Parameter } & \multicolumn{2}{c}{ Treatments } & Pooled & p-value \\
\cline { 2 - 3 } & Control & $\mathrm{SW}$ & $\mathrm{SE}$ & \\
\hline Carcass weight $(\mathrm{kg})$ & 454.15 & 461.85 & 13.35 & 0.70 \\
Dressing-out (\%) & 60.55 & 60.49 & 2.21 & 0.99 \\
Meat quality grade $^{2}$ & 3.75 & 3.88 & 0.27 & 0.75 \\
Carcass yield grade $^{3}$ & 1.25 & 1.50 & 0.22 & 0.44 \\
\hline Pooled SE, pooled standard error. \\
${ }^{1}$ Data presented as the mean value of five replicate steers for each \\
treatment $(\mathrm{n}=5$ ). \\
${ }^{2}$ Meat quality grades, $5=1++; 4=1+; 3=1 ; 2=2 ; 3=1$ (According to \\
KAPE, 2012). \\
${ }^{3}$ Carcass yield grades, $3=\mathrm{A} ; 2=\mathrm{B} ; 1=\mathrm{C}$ grade. \\
Significantly differed $(\mathrm{p}<0.05) ;$ tendency $(\mathrm{p}<0.10)$.
\end{tabular}


Table 6. Effect of dietary sea mustard (Undaria pinnatifida) byproduct (SW) on longissimus muscle chemical composition and cholesterol content (per $100 \mathrm{~g}$ ) of Hanwoo carcass ${ }^{1}$

\begin{tabular}{lcccc}
\hline \multirow{2}{*}{ Parameter } & \multicolumn{2}{c}{ Treatment } & Pooled & \multirow{2}{*}{ p-value } \\
\cline { 2 - 3 } & Control & SW & SE & \\
\hline Moisture $(\mathrm{g})$ & 61.67 & 59.91 & 1.61 & 0.49 \\
CP $(\mathrm{g})$ & 20.80 & 19.54 & 0.88 & 0.36 \\
Crude fat $(\mathrm{g})$ & 16.64 & 19.70 & 2.51 & 0.42 \\
Crude ash $(\mathrm{g})$ & 0.89 & 0.86 & 0.04 & 0.60 \\
Cholesterol $(\mathrm{mg})$ & 66.26 & 59.50 & 1.87 & 0.04 \\
\hline
\end{tabular}

Pooled SE, pooled standard error; $\mathrm{CP}$, crude protein.

${ }^{1}$ Data presented as the mean value of five replicate steers for each treatment $(n=5)$.

Significantly differed $(\mathrm{p}<0.05)$; tendency $(\mathrm{p}<0.10)$.

significant effect on moisture, $\mathrm{CP}$, crude fat, or crude ash contents of loin meat. Zaki et al. (1994) reported no significant difference in fish muscle DM and CP contents when seaweed was supplemented in carp fish. The results of the present study are in agreement with the findings of several other investigations (El-Deek et al., 1985; Taher, 1986). However, Zaki et al. (1994) reported increased ash percentages in fish muscle by increasing the level of seaweed supplementation.

Meat cholesterol concentration in the SW group was significantly lower $(\mathrm{p}<0.05)$ than in the control group (Table 6). Our results agree with Murata et al. (2002) who reported that dietary supplementation of dried SW powder significantly decreases the concentrations of serum and liver cholesterol in rats. Seamustard is also a useful food for the prevention and treatment of hypertriacylglycerolemia (Murata et al., 1999). In particular, alginic acid, the mucopolysaccharide in SW, is effective in discharging heavy metal and radioactive substances from the body and in decreasing cholesterol, as well as preventing high blood pressure and glycosuria (Kim and Kim, 1982; Kim and Cheong, 1984; Choi et al., 1991). Furthermore, it has been reported that SW contains $\sim 30 \mathrm{~g} / 100 \mathrm{~g}$ of alginate and dietary alginate has been shown to decrease cholesterol concentrations in serum and liver of rats (Eaton et al., 1996; Wu and Peng, 1997). The effect of dietary SW on serum cholesterol concentration may be due to fucosterol (Tsuda et al., 1957) and/or dietary fiber, as both reduce serum cholesterol concentrations by reducing cholesterol absorption in the small intestine (Murata et al., 1999). Binding tendency of terrestrial tannin contents of brown seaweed ( $U$. pinnatifida) has an inhibitory effect upon ruminal microorganisms (Min et al., 2003; 2005).

\section{Fatty acid composition}

Fatty acid composition of beef is an important issue because fat tissue containing abundant MUFA contributes positively to meat flavor and tenderness (Dryden et al., 1970; Melton et al., 1982; Sturdivant et al., 1992; Jeremiah,
1996), whereas increased concentrations of SFA are associated with increasing risk of cardiovascular diseases (Kromhout et al., 1995). Fatty acid concentrations in Hanwoo meat found in the current study are shown in Table 7. Of the individual fatty acids, the concentration of myristic acid (C14:0) and palmitoleic acid (C16:0) significantly decreased in the SW dietary group compared with the controls $(\mathrm{p}<0.05)$. Whereas, stearic acid $(\mathrm{C} 18: 0)$ and linolenic acid (C18:3n-3) concentrations were significantly increased in SW dietary group compared to control $(\mathrm{p}<0.05)$. The SFA and unsaturated fatty acid concentrations in the two groups were similar in the study. An increased concentration of $n-3$ fatty acid content and a reduced ratio of poly unsaturated fatty acid (PUFA)/SFA and $n-6 / n-3$ were found in SW supplemented group compared to control $(\mathrm{p}<0.05)$. Phlorotannins are the only group of tannins present in brown seaweed (Ragan and Glombitza, 1986; Arnold and Targett, 1998; Mueller-Harvey, 2006; Fung et al., 2013) that might be responsible for the elevated concentration of $\mathrm{C} 18: 3 \mathrm{n}-3$ and reduced C14:0 content of muscle. The binding tendency of tannins (Jones and Mangan, 1977) inhibits the growth of ruminal bacteria (Min et al., 2003). Tannins reduced ruminal biohydrogenation (BH) through the inhibition of the proliferation of ruminal microorganisms rather than by a direct interaction of tannins with the enzymes that operate in the BH pathway (Vasta et al., 2009). Biohydrogenation of linoleic (C18:2n-6) and C18:3n-3 leads to a large number of trans $\mathrm{C} 18: 1$ isomers which are accumulated in the tissues (Mosley et al., 2002; Bessa et al., 2007). The most effective way to enhance the concentration of rumenic acid in ruminant products is to favor the ruminal production of vaccenic acid (C18:ln-7) (Griinari et al., 2000; Sackmann et al., 2003). Vasta et al. (2009a) found an increased tendency of C18:3n-3 concentration, increased PUFA and decreased SFA content of longissimus muscle in lamb when supplied diets contained tannin compared to non-tannin feed. Seaweeds contain PUFAs as high as those of terrestrial vegetables (Darcy-Vrillon, 1993). The elevated concentration of n-3 fatty acids in the SW fed animals corresponds with the reported (Pulz and Gross, 2004; Plaza et al., 2010) substantial amounts of n-3 fatty acids in seaweed, which are of particular interest in animal feeding (Kouba and Mourot, 2011). Increased intake of C18:2n-6 increased the proportion of rumenic acid (Bauman et al., 2000). U. pinnatifida contained the essential fatty acid C18:3n-3 and the eicosanoid precursors $C 20: 4 n-6$ and C20:5n-3 (Banaimoon, 1992). According to Mahan and Escott-Stump (2000), U. pinnatifida may play the vital role for the reduction of $n-6 / n-3$ ratio. This was also attributed to a reduced activity of ruminal microorganisms due to the presence of terrestrial tannins in brown seaweed (Haslam, 1989; Waterman and Mole, 1994). 
Table 7. Effect of dietary sea mustard ( Undaria pinnatifida) by-product (SW) on longissimus muscle fatty acid compositions ${ }^{1}$

\begin{tabular}{|c|c|c|c|c|}
\hline \multirow{2}{*}{$\begin{array}{l}\text { Fatty acid } \\
\text { (\% of total fatty acid) }\end{array}$} & \multicolumn{2}{|c|}{ Treatment } & \multirow{2}{*}{ Pooled SE } & \multirow{2}{*}{ p-value } \\
\hline & Control & SW & & \\
\hline Myristic acid (C14:0) & 3.02 & 2.61 & 0.10 & 0.02 \\
\hline Palmitic acid (C16:0) & 27.21 & 26.84 & 1.04 & 0.81 \\
\hline Palmitoleic acid (C16:ln-7) & 4.51 & 3.18 & 0.17 & 0.0001 \\
\hline Stearic acid (C18:0) & 10.67 & 13.45 & 0.86 & 0.04 \\
\hline Oleic acid (C18:1 n-9) & 51.27 & 50.92 & 3.04 & 0.94 \\
\hline Vaccenic acid (C18:1 n-7) & 0.14 & 0.10 & 0.02 & 0.21 \\
\hline Linoleic acid (C18:2 n-6) & 2.32 & 2.12 & 0.08 & 0.11 \\
\hline$\gamma$-Linoleic acid (C18:3 n-6) & 0.07 & 0.08 & 0.01 & 0.51 \\
\hline Linolenic acid (C18:3 n-3) & 0.09 & 0.15 & 0.02 & 0.02 \\
\hline Eicosenoic acid (C20:1 n-9) & 0.51 & 0.43 & 0.08 & 0.48 \\
\hline Arachidonic acid (C20:4 n-6) & 0.18 & 0.18 & 0.03 & 0.98 \\
\hline$\Sigma$ SFA & 40.91 & 42.90 & 1.47 & 0.36 \\
\hline$\Sigma \mathrm{UFA}$ & 59.10 & 57.14 & 3.21 & 0.68 \\
\hline (MUFA+PUFA)/SFA & 1.45 & 1.34 & 0.06 & 0.24 \\
\hline$\Sigma$ MUFA & 56.43 & 54.63 & 3.15 & 0.70 \\
\hline इPUFA & 2.66 & 2.51 & 0.10 & 0.29 \\
\hline MUFA/SFA & 1.38 & 1.27 & 0.06 & 0.25 \\
\hline PUFA/SFA & 0.07 & 0.06 & 0.002 & 0.05 \\
\hline$\Sigma \mathrm{n}-3$ & 0.10 & 0.13 & 0.01 & 0.04 \\
\hline$\Sigma \mathrm{n}-6$ & 2.57 & 2.38 & 0.09 & 0.19 \\
\hline$n-6 / n-3$ & 29.03 & 18.79 & 2.08 & 0.01 \\
\hline
\end{tabular}

Pooled SE, pooled standard error; SFA, saturated fatty acid; UFA, unsaturated fatty acids; MUFA, monounsaturated fatty acid; PUFA, poly unsaturated fatty acids; $n-3, n-3$ polyunsaturated fatty acids; $n-6, n-6$ polyunsaturated fatty acids.

${ }^{1}$ Data presented as the mean value of five replicate steers for each treatment $(\mathrm{n}=5)$.

Significantly differed $(\mathrm{p}<0.05)$; tendency $(\mathrm{p}<0.10)$.

\section{IMPLICATIONS}

Dietary supplementation of SW (Undaria pinnatifida) by-product at the rate of $2 \%$ in Hanwoo steers had a significant positive impact on growth performance as revealed from increased $\mathrm{ADG}$ and feed efficiency and immune status (increased IgG). Furthermore, it significantly reduced cholesterol concentration and improved fatty acid profile that can reduce public health concerns on beef consumption. Utilization of locally available SW, a marine by-product, in animal feeds can be used for making animal production more sustainable and reduce marine environment pollution with undue dumping of the same.

\section{ACKNOWLEDGMENTS}

The research was supported by the Rural Development Administration and the Korean Ministry of Knowledge Economy, Korea.

\section{REFERENCES}

Allen, V., K. Pond, K. Saker, J. P. Fontenot, C. P. Bagley, R. L. Ivy, R. R. Evans, R. E. Schmidt, J. H. Fike, X. Zhang, J. Y. Ayad, C. P. Brown, M. F. Miller, J. L. Montgomery, J. Mahan, D. B.
Wester, and C. Melton. 2001. Tasco: Influence of a brown seaweed on antioxidants in forages and livestock-a review. J. Anim. Sci. 79:E21-E31.

Al-Shorepy, S. A., G. A. Alhadrami, and I. A. Jamali. 2001. Effect of feeding diets containing seaweed on weight gain and carcass characteristics of indigenous lambs in the United Arab Emirates. Small Rumin. Res. 41:283-287.

Anderson, M., J. Blanton, J. Gleghorn, S. Kim, and J. Johnson. 2006. Ascophyllum nodosum supplementation strategies that improve overall carcass merit of implanted English crossbred cattle. Asian Australas. J. Anim. Sci. 19:1514-1518.

AOAC. 2000. Official Methods of Analysis. 17th edn. Association of Official Analytical Chemists, Washington, DC, USA.

Applegate, R. D. and P. B. Gray. 1995. Nutritional value of seaweed for ruminants. Rangifer 15:15-28.

Arieli, A., D. Sklan, and G. Kissil. 1993. A note on the nutritive value of Ulva lactuca for ruminants. Anim. Sci. 57:329-331.

Arnold, T. M. and N. M. Targett. 1998. Quantifying in situ rates of phlorotannin synthesis and polymerization in marine brown algae. J. Chem. Ecol. 24:577-595.

Bach, S. J., Y. Wang, and T. A. McAllister. 2008. Effect of feeding sun-dried seaweed (Ascophyllum nodosum) on fecal shedding of Escherichia coli $\mathrm{O} 157: \mathrm{H} 7$ by feedlot cattle and on growth performance of lambs. Anim. Feed Sci. Technol. 142:17-32.

Banaimoon, S. 1992. Fatty acids in marine macroalgae from Southern Yemen (Hadramout) including occurrence of eicosatetraenoic (20: 4) and eicosapentaenoic (20: 5) acids. Botanica Marina 35:165-168. 
Barry, T. N. and W. C. McNabb. 1999. The implications of condensed tannins on the nutritive value of temperate forages fed to ruminants. Br. J. Nutr. 81:263-272.

Bauman, D. E., L. H. Baumgard, B. A. Corl, and J. M. Griinari. 2000. Biosynthesis of conjugated linoleic acid in ruminants. J. Anim. Sci. 77(E-suppl):1-15.

Bessa, R. J. B., S. P. Alves, E. Jeronimo, C. M. Alfaia, J. A. M. Prates, and J. Santos-Silva. 2007. Effect of lipid supplements on ruminal biohydrogenation intermediates and muscle fatty acids in lamb. Eur. J. Lipid Sci. Technol. 109:868-883.

Braden, K. W., J. R. Jr. Blanton, J. L. Montgomery, E. van Santen, V. G. Allen, and M. F. Miller. 2007. Tasco supplementation: Effect on carcass characteristics, sensory attributes and retail display shelf-life. J. Anim. Sci. 85:754-768.

Brown, G. D. and S. Gordon. 2005. Immune recognition of fungal $\beta$-glucans. Cell. Microbiol. 7:471-479.

Cameron, N. and M. Enser. 1991. Fatty acid composition of lipid in Longissimus dorsi muscle of Duroc and British Landrace pigs and its relationship with eating quality. Meat Sci. 29:295307.

Cherian, G., R. K. Selvaraj, M. P. Goeger, and P. A. Stitt. 2002. Muscle fatty acid composition and thiobarbituric acid-reactive substances of broilers fed different cultivars of sorghum. Poult. Sci. 81:1415-1420.

Choi, J. H., J. I. Kim, I. S. Kim, and T. H. Yoon. 1991. Studies on anti-aging action of brown algae (Undaria pinnatifida): 1 . Dose effect of alginic acid as a modulator of anti-aging action in serum lipids. Korean J. Gerontol. 1:173-178.

Darcy-Vrillon, B. 1993. Nutritional aspects of the developing use of marine macroalgae for the human food industry. Int. J. Food Sci. Nutr. 44:23-35.

Dryden, F. and J. Maechello. 1970. Influence of total lipid and fatty acid composition upon the palatability of three bovine muscles. J. Anim. Sci. 31:36-41.

Dubeski, P. L. 1999. Nutrition and immune function in cattle. In: Proceedings of Western Nutrition Conference, Calgary, AB, Canada. pp. 9-22.

Eaton, S., K. Bartlett, and M. Pourfarzam. 1996. Mammalian mitochondrial beta-oxidation. Biochem. J. 320:345-357.

EI-Deek, A. A., N. S. Isshak, S. Hamdy, N. Badawy, and M. A. Asar. 1985. Performance of two strains of laying hens fed on practical diets containing different levels of seaweed during the rearing and laying stages. Egypt. Poult. Sci. 5:1-11.

Fike, J. H., V. G. Allen, R. E. Schmidt, X. Zhang, J. P. Fontenot, C. P. Bagley, R. L. Ivy, R. R. Evans, R. W. Coelho, and D. B. Wester. 2001. Tasco-forage: I. Influence of a seaweed extract on antioxidant activity in tall fescue and in ruminants. J. Anim. Sci. 79:1011-1021.

Fleurence, J. 1999. Seaweed proteins: Biochemical, nutritional aspects and potential uses. Trends Food Sci. Technol. 10:25-28.

Fung, A., N. Hamid, and J. Lu. 2013. Fucoxanthin content and antioxidant properties of Undaria pinnatifida. Food Chem. 136:1055-1062.

Griinari, J. M., B. A. Corl, S. H. Lacy, P. Y. Chouinard, K. V. V. Nurmela, and D. E. Bauman. 2000. Conjugated linoleic acid is synthesized endogenously in lactating dairy cows by $\Delta^{9}$ desaturase. J. Nutr. 130:2285-2291.

Gupta, S. and N. Abu-Ghannam. 2011. Bioactive potential and possible health effects of edible brown seaweeds. Trends Food Sci. Technol. 22:315-326.

Han, S. W. and B. O. Lee. 2010. A Study on the purchasing behaviour of consumers for domestic and imported beef in Korea. J. Agric. Life Sci. 22:73-89.

Harvey, R. W., K. M. Snyder, and J. W. Spears. 1982. Alternative protein sources for growing cattle fed corn silage. Page 17 in North Carolina State Univ. Res. Rep., Raleigh, USA.

Haslam, E. 1989. Plant polyphenols: Vegetable tannins revisited. Cambridge University Press, Cambridge, UK.

Holdt, S. L. and S. Kraan. 2011. Bioactive compounds in seaweed: Functional food applications and legislation. J. Appl. Phycol. 23:543-597.

Hwang, H., T. Chen, R. G. Nines, H. C. Shin, and G. D. Stoner. 2006. Photochemoprevention of UVB-induced skin carcinogenesis in SKH-1 mice by brown algae polyphenols. Int. J. Cancer 119:2742-2749.

Jeremiah, L. 1996. The influence of subcutaneous fat thickness and marbling on beef: Palatability and consumer acceptability. Food Res. Int. 29:513-520.

Jones, W. T. and J. L. Mangan. 1977. Complexes of the condensed tannins of sainfoin (Onobrychis viciifolia Scop.) with fraction 1 leaf protein and with submaxillary-mucoprotein, and their reversal by polyethylene glycol and $\mathrm{pH}$. J. Food Sci. Agric. 28:126-136.

Kandasamy, S., W. Khan, F. Evans, A. T. Critchley, and B. Prithiviraj. 2012. Tasco ${ }^{\circledR}$ : A product of Ascophyllum nodosum enhances immune response of Caenorhabditis elegans against Pseudomonas aeruginosa infection. Mar. Drugs 10:84-105.

KAPE. 2012. The beef carcass grading. Korea Institute for Animal Products Quality Evaluation. http://www.ekape.or.kr/view/eng/ system/beef.asp Accessed May 15, 2012.

Kim, K. and C. Kim. 1982. Studies on the manufacture of Underia pinnatifida laver and it's physicochemical properties: 1 . Histochemical properties. Korean J. Food Sci. Tech. 14:336341.

Kim, K. and J. Cheong. 1984. Optimum conditions for extracting alginic acid from Undaria pinatifida and amino acid composition of its extraction residue. Korean J. Food Sci. Tech. 16:336-340.

Kim, K. H., Y. S. Kim, Y. K. Lee, and M. B. Baik. 2000. Postmortem muscle glycolysis and meat quality characteristics of intact male Korean native (Hanwoo) cattle. Meat Sci. 55:4752.

King, A. J., P. Paniangvait, A. D. Jones, and J. B. German. 1998. Rapid method for quantification of cholesterol in turkey meat and products. J. Food Sci. 63:382-385.

Klopfenstein, T. and F. Goedeken. 1986. Animal protein products: Bypass potential. Feed Management 37:12.

Kolb, N., L. Vallorani, N. Milanovic, and V. Stocchi. 2004. Evaluation of marine algae wakame (Undaria pinnatifida) and kombu (Laminaria digitata japonica) as food supplements. Food Technol. Biotechnol. 42:57-62.

Korean Ministry for Food, Agriculture, Forestry and Fisheries. 2008. Guidelines for the care and use of animals in research. (Korean Ministry for Food, Agriculture, Forestry and Fisheries: Seoul, Korea)

Kouba, M. and J. Mourot. 2011. A review of nutritional effects on 
fat composition of animal products with special emphasis on n-3 polyunsaturated fatty acids. Biochimie 93:13-17.

Krakowski, L., J. Krzyżanowski, Z. Wrona, and A. K. Siwicki. 1999. The effect of nonspecific immunostimulation of pregnant mares with 1, 3/1, 6 glucan and levamisole on the immunoglobulins levels in colostrum, selected indices of nonspecific cellular and humoral immunity in foals in neonatal and postnatal period. Vet. Immunol. Immunopathol. 68:1-11.

Krakowski, L., J. Krzyżanowski, Z. Wrona, K. Kostro, and A. K. Siwicki. 2002. The influence of nonspecific immunostimulation of pregnant sows on the immunological value of colostrum. Vet. Immunol. Immunopathol. 87:89-95.

Kromhout, D., A. Menotti, B. Bloemberg, C. Arvanis, H. Blackburn, R. Buzina, A. S. Dontas, F. Fidanza, S. Giampaoli, A. Jansen, M. Karvonen, M. Katan, A. Nissinen, S. Nedeljkovic, J. Pekkanen, M. Pekkanen, S. Punsar, L. Rasanen, B. Simic, and H. Toshima. 1995. Dietary saturated and trans fatty acids and cholesterol and 25-year mortality from coronary heart disease: The seven countries study. Prev. Med. 24:308-315.

Laborde, F. L., I. B. Mandell, J. J. Tosh, J. W. Wilton, and J. G. Buchanan-Smith. 2001. Breed effects on growth performance, carcass characteristics, fatty acid composition and palatability attributes in finishing steers. J. Anim. Sci. 79:355-365.

Le Tutour, B. 1990. Antioxidative activities of algal extracts, synergistic effect with vitamin E. Phytochemistry 29:37593765.

Lee, K. N., D. Kritchevsky, and M. W. Pariza. 1994. Conjugated linoleic acid and atherosclerosis in rabbits. Atherosclerosis 108:19-25.

Leonard, S. G., T. Sweeney, B. Bahar, K. M. Pierce, B. P. Lynch, and J. V. O'Doherty. 2010. The effects of maternal dietary supplementation with seaweed extract and fish oil on the humoral immune response and performance of suckling piglets. Livest. Sci. 134:211-214.

Mahan, K. L. and S. Escott-Stump. 2000. Nutrition and diet therapy Krause. McGraw-Hill Interamericana, Madrid, Spain.

Mattson, F. H. and S. M. Grundy. 1985. Comparison of effects of dietary saturated, monounsaturated and polyunsaturated fatty acids on plasma lipids and lipoproteins in man. J. Lipid Res. 26:194-202.

McHugh, D. J. 2003. A Guide to the Seaweed Industry. FAO Fish Tech. Pap. Rome, Italy. 441:105.

Melton, S., M. Amiri, G. Davis, and W. Backus. 1982. Flavor and chemical characteristics of ground beef from grass-, foragegrain- and grain-finished steers. J. Anim. Sci. 55:77-87.

Min, B. R., G. T. Attwood, W. C. McNabb, A. L. Molan, and T. N. Barry. 2005. The effect of condensed tannins from Lotus corniculatus on the proteolytic activities and growth of rumen bacteria. Anim. Feed Sci. Technol. 121:45-58.

Min, B. R., T. N. Barry, G. T. Attwood, and W. C. McNabb. 2003. The effect of condensed tannins on the nutrition and health of ruminants fed fresh temperate forages: A review. Anim. Feed Sci. Technol. 106:3-19.

Min, B. R., T. N. Barry, W. C. McNabb, and P. D. Kemp. 1998. Effect of condensed tannins on the production of wool and on its processing characteristics in sheep grazing Lotus corniculatus. Aust. J. Agric. Res. 49:599-606.
Mohammed, A. M., M. Atta, S. A. Babiker, and O. A. El Khidir. 2007. Economic evaluation of beef production from Western Sudan Baggara bulls fattened to different slaughter weights. Sudan Academy of Sciences 1:19-29.

Mosley, E. E., G. L. Powell, M. B. Riley, and T. C. Jenkins. 2002. Microbial biohydrogenation of oleic acid to trans isomers in vitro. J. Lipid Res. 43:290-296.

Mueller-Harvey, I. 2006. Review: Unravelling the conundrum of tannins in animal nutrition and health. J. Sci. Food Agric. 86:2010-2037.

Murata, M., K. Ishihara, and H. Saito. 1999. Hepatic fatty acid oxidation enzyme activities are stimulated in rats fed the brown seaweed, Undaria pinnatifida (wakame). J. Nutr. 129:146-151.

Murata, M., Y. Sano, K. Ishihara, and M. Uchida. 2002. Dietary fish oil and Undaria pinnatifida (wakame) synergistically decrease rat serum and liver triacylglycerol. J. Nutr. 132:742747.

Nakamura, T., K. Nagayama, K. Uchida, and R. Tanaka. 1996. Antioxidant activity of phlorotannins isolated from the brown alga Eisenia bicyclis. Fisheries Sci. 62:923-926.

O’Doherty, J. V., S. Dillon, S. Figat, J. J. Callan, and T. Sweeney. 2010. The effect of lactose inclusion and seaweed extract derived from Laminaria spp. on performance, digestibility of diet components and microbial populations in newly weaned pigs. Anim. Feed Sci. Technol. 157:173-180.

OFSI 2013. Oceans Fisheries Science Institute, Wando-gun, Jeollanam-do, Korea. http://news.naver.com/main/read.nhn? mode $=$ LSD\&mid=sec\&sid1 $=102 \&$ oid $=003 \&$ aid $=0005009404$ (Korean), http://ofsi.jeonnam.go.kr/?pid=B (English).

Plaza, M., S. Santoyo, L. Jaime, G. García-Blairsy Reina, M. Herrero, F. Señoráns, and E. Ibáñez. 2010. Screening for bioactive compounds from algae. J. Pharm. Biomed. Anal. 51:450-455.

Preston, T. R. and M. B. Willis. 1974. Intensive beef production In: 2nd Ed. (Ed. Anonymous). Pergamon Press Ltd., London.

Pulz, O. and W. Gross. 2004. Valuable products from biotechnology of microalgae. Appl. Microbiol. Biotechnol. 65:635-648.

Ragan, M. A. and K. W. Glombitza. 1986. Phlorotannins, brown algal polyphenols. Prog. Phycol. Res. 4:129-241.

Read, S. M., G. Currie, and A. Bacic. 1996. Analysis of the structural heterogeneity of laminarin by electrosprayionisation-mass spectrometry. Carbohydr. Res. 281:187-201.

Sackmann, J. R., S. K. Duckett, M. H. Gillis, C. E. Realini, A. H. Parks, and R. B. Eggelston. 2003. Effects of forage and sunflower oil levels on ruminal biohydrogenation of fatty acids and conjugated linoleic acid formation in beef steers fed finishing diets. J. Anim. Sci. 81:3174-3181.

Saker, K. E., J. H. Fike, H. Veit, and D. L. Ward. 2004. Brown seaweed-(TascoTM) treated conserved forage enhances antioxidant status and immune function in heat-stressed wether lambs. J. Anim. Physiol. Anim. Nutr. 88:122-130.

Saker, K. E., V. G. Allen, J. P. Fontenot, C. P. Bagley, R. L. Ivy, R. R. Evans, and D. B. Wester. 2001. Tasco-Forage: II. Monocyte immune cell response and performance of beef steers grazing tall fescue treated with a seaweed extract. J. Anim. Sci. 79:1022-1031. 
SAS Institute Inc. 2003. SAS User's Guide. 9.1 Edition, SAS Institute Inc., Cary, NC, USA

Sturdivant, C. A, D. K. Lunt, G. C. Smith, and S. B. Smith. 1992. Fatty acid composition of subcutaneous and intramuscular adipose tissues and M. Longissimus dorsi of Wagyu cattle. Meat Sci. 32:449-458.

Swartz, L. A., A. J. Heinrichs, G. A. Varga, and L. D. Muller. 1989. Varying undegradable intake protein on feed intake and growth of dairy calves from birth to 24 weeks of age. J. Dairy Sci. 72(Suppl. 1):529.

Taher, M. 1986. The Use of Marine Seaweed in Broilers Nutrition. M. Sc. Thesis, Alexandria University, Alexandria, Egypt.

Tomlinson, D. J., R. E. James, and M. L. McGilliard. 1989. Effect of TDN and degradable protein on intake, daily gain and subsequent lactation of Holstein heifers. J. Dairy Sci. 72(Suppl. 1):416 (Abstr.)

Tomlinson, D. L., R. E. James, G. L. Bethard, and M. L. McGilliard. 1997. Influence of undegradability of protein in the diet on intake, daily gain, feed efficiency, and body composition of Holstein heifers. J. Dairy Sci. 80:943-948.

Tsuda, K., S. Akagi, and Y. Kishida. 1957. Discovery of cholesterol in some red algae. Science 126(3279):927-928.

Turner, J. L., S. S. Dritz, J. J. Higgins, and J. E. Minton. 2002. Effects of Ascophyllum nodosum extracts on growth performance and immune function of young pigs challenged with Salmonella typhimurium. J. Anim. Sci. 80:1947-1953.

Van Soest, P. J., J. B. Robertson, and B. A. Lewis. 1991. Methods for dietary fiber, neutral detergent fiber, and nonstarch polysaccharides in relation to animal nutrition. J. Dairy Sci. 74:3583-3597.

Vasta, V., H. P. S. Makkar, M. Mele, and A. Priolo. 2009. Ruminal biohydrogenation as affected by tannins in vitro. Br. J. Nutr. 102:82-92.
Vasta, V., M. Mele, A. Serra, M. Scerra, G. Luciano, M. Lanza, and A. Priolo. 2009a. Metabolic fate of fatty acids involved in ruminal biohydrogenation in sheep fed concentrate or herbage with or without tannins. J. Anim. Sci. 87:2674-2684.

Volman, J. J., J. D. Ramakers, and J. Plat. 2008. Dietary modulation of immune function by $\beta$-glucans. Physiol. Behav. 94:276-284.

Wang, Y., B. P. Berg, L. R. Barbieri, D. M. Veira, and T. A. McAllister. 2006. Comparison of alfalfa or mixed alfalfasainfoin pastures for grazing cattle: Effects on incidence of bloat, ruminal fermentation, and feed intake. Can. J. Anim. Sci. 86:383-392.

Wang, Y., G. B. Douglas, G. C. Waghorn, T. N. Barry, and A. G. Foote. 1996. The effect of condensed tannins in Lotus corniculatus upon lactation performance in twin-bearing ewes. J. Agric. Sci. (Camb.). 126:353-362.

Waterman, P. G. and S. Mole. 1994. Analysis of phenolic plant metabolites. In: Methods in Ecology. Blackwell Scientific Publications, Oxford, UK

Wu, J. and S. Peng. 1997. Comparison of hypolipidemic effect of refined konjac meal with several common dietary fibers and their mechanisms of action. Biomed. Environ. Sci. 10:27-37.

Yang, C. J., I. Y. Yang, D. H. Oh, I. H. Bae, S. G. Cho, I. G. Kong, D. Uuganbayar, I. S. Nou, and K. S. Choi. 2003. Effect of green tea by-product on performance and body composition in broiler chicks. Asian Australas. J. Anim. Sci. 16:867-872.

Zaki, M. A., A. M. Nour, E. Omar, and A. E. Tag El-Din. 1994. The use of seaweed meal in feeding common carp (Cyprinus carpio). Asian Australas. J. Anim. Sci. 7:183-189.

Zalabak, V., J. Kejmar, M. Rosa, and F. Stros. 1990. Algae. In: Nonconventional Feedstuffs in the Nutrition of Farm Animals (Ed. K. Boda). Elsevier, Amsterdam, The Netherlands.

Zerbini, E. and C. E. Polan. 1985. Protein sources evaluated for ruminating Holstein calves. J. Dairy Sci. 68:1416-1424. 